\title{
Screening cassava genotypes in two agroecological zones of Nigeria using tuberous root poundability
}

\author{
S. O. AKPAROBI \\ Department of Agronomy, Faculty of Agriculture, Delta State University, Asaba Campus, Delta \\ State, Nigeria
}

\begin{abstract}
Twelve cassava genotypes were evaluated in two agroecological zones (Ibadan: $25 \pm 5{ }^{\circ} \mathrm{C}$ and Jos: $14 \pm$ $5{ }^{\circ} \mathrm{C}$ ) to determine the tuberous root poundability at 3 , 6, 9 and 12 months after planting (MAP). The results showed that there were no significant differences $(P<0.05)$ in tuberous root poundability between the two locations and years throughout the sampling periods. Also, genotypic differences $(P<0.05)$ were not observed among the cassava genotypes for tuberous root poundability either across or within locations. Isunikankiyan, TME I, TMS 50395 and TMS 30572 produced the lowest values for tuberous root poundability of $1.2,1.3,1.2$ and 1.4 for $3,6,9$ and 12 MAP, respectively. Genotypic differences $(P<0.05)$ were observed among the tested genotypes for total dry tuberous root yield per hectare. The highest tuberous root yields per hectare were produced by TMS 30572, TMS 50395, TMS 91934 and TME 1. The results of this study suggest that TME 1, TMS 50395 and TMS 30572 were poundable and also had high tuberous dry root matter. It is recommended that these varieties be made available for farmers in farm testing and also be used for further breeding programmes for incorporation of the poundability characteristics.
\end{abstract}

Original scientific paper. Received 10 Mar 05; revised 10 Sep 07.

\begin{abstract}
RÉSUMÉ
Aкparobi, S. O.: Despitage de génotype de manioc en deux zones agroécologiques du Nigéria utilisant la méthode de la qualité de pilonnage de racine tubéreuse. Douze génotypes de manioc étaient évalués dans deux zones agroécologiques (Ibadan : $25 \pm 5{ }^{\circ} \mathrm{C}$ et Jos: $18 \pm 5$ ${ }^{\circ} \mathrm{C}$ ), pour déterminer la qualité de pilonnage de la racine tubéreuse à 3, 6, 9 et 12 mois après la plantation (MALP). Les résultats montraient qu'il n'y avait pas des différences $(P<0.05)$ considérables dans la qualité de pilonnage de racine tubéreuse entre les deux endroits et les deux années (1994 à 1996) partout dans les périodes d'échantillonage. En outre les différences génotypiques $(P<0.05)$ n' étaient pas observées parmi les génotypes de manioc pour la qualité de pilonnage de la racine tubéreuse soit à travers soit à l'intérieur d' endroits. Isunikankiyan, TME 1, TMS 50395 et TMS 30572 donnaient les plus faibles valeurs de qualité de pilonnage de racine tubéreuse de $1.2,1.3,1.2$ et 1.4 respectivement pour $3,6,9$ et 12 MALP. Les différences génotypiques $(P<0.05)$ étaient observées parmi les génotypes mis à l'essai pour le rendement par hectare de racine tubéreuse sèche totale. Les plus élevés de rendement par hectare de racine tubéreuse étaient produits par TMS 30572, TMS 50395, TMS 91934 et TME 1. Les résultats de cette étude suggèrent que TME 1, TMS 50395 et TMS 30572 étaient pilonnables et aussi avaient la matière de racine tubéreuse séche élevée. Nous recommandons que ces variétés soient faites disponibles pour les agriculteurs pour l'essai sur le champ et aussi d'être utilisé pour autres programmes de reproduction pour l'incorporation des caractères de pilonnage.
\end{abstract}

\section{Introduction}

Cassava tubers form one of the major staple foods in the world (FAO, 1996; Akparobi, Ekanayake \& Togun, 2002). Cassava will continue to assume greater importance with time as a major source of carbohydrate for human consumption in the tropics and sub-tropics where the low per capita income will not permit a change in dietary habits (Carter et al., 1992; CIAT, 1993).

The two broad consumption patterns for 
cassava are in either the fresh or dry form (Hahn \& Keyser, 1985; Sanni, 1994; Odogola, 1994). In the fresh form, cassava may be eaten raw in small quantities as snack, and may be boiled and pounded into 'fufu'. The dry form involves peeling of the roots, chipping, slicing, and pounding to obtain cassava meal called 'fufu'. Poundability of cassava roots is a primary factor in the choice of cassava by farmers and consumers (Cock, 1985; Dixon, Asiedu \& Hahn, 1994). Poundability of the tuberous root is also of economic importance (Cock, 1985; Dixon et al., 1994; Nweke, 1996). It is, therefore, essential to incorporate traits such as poundability of roots in developing cassava varieties.

Traits such as poundability are evaluated using subjective estimates (Dixon et al., 1994). This study investigated screening of cassava genotypes in two contrasting agroecological zones of Nigeria for changes in biochemical parameter of cassava tuberous roots using poundability.

\section{Materials and methods}

Experimental sites

The experimental sites were at Jos plateau (midaltitude) and Ibadan (lowland-savanna transition zone). Two experiments were conducted during the 1994/95 and 1995/96 crop seasons at the International Institute of Tropical Agriculture (IITA), Ibadan and field stations of the National Root Crop Research Institute (Vom \& Heipang) in Jos plateau. In 1994/95 crop season, cassava stem cuttings were planted on 5 May 1994 and 13 May 1994 at Ibadan and Jos, respectively. In 1995/ 96 crop season, cassava stem cuttings were planted on 10 May 1995 and 20 May 1995 at Ibadan and Jos, respectively. The two locations represent contrasting agroecological zones: Ibadan (altitude, $210 \mathrm{~m}$ above sea level [masl]; latitude, $4^{\circ} 46^{\prime} \mathrm{N}$; longitude, $2^{\circ} 34^{\prime} \mathrm{E}$; temperature, $27 \pm 6^{\circ} \mathrm{C}$; relative humidity, $68-93$ per cent; mean annual rainfall, $1254 \mathrm{~mm}$ ) and Jos plateau (Vom: altitude, 1280 masl; latitude, $9^{\circ} 55^{\prime} \mathrm{N}$; longitude, $8^{\circ} 9^{\prime} \mathrm{E}$; temperature, $18 \pm 5^{\circ} \mathrm{C}$; relative humidity,
60-88 per cent; mean annual rainfall, $1011 \mathrm{~mm}$; Heipang: altitude, 1290 masl; latitude, $9^{\circ} 38^{\prime} \mathrm{N}$; longitude, $8^{\circ} 9^{\prime} \mathrm{E}$; temperature, $17 \pm 5^{\circ} \mathrm{C}$; relative humidity, $65-85$ per cent; mean annual rainfall, 1120 $\mathrm{mm})$. The soil at Ibadan is classified as Oxic paleuestalf, Alagba soil series (Greenland, 1981); while in Jos plateau, the soil is Ferruginous tropical soil (Kowal \& Knabe, 1972).

\section{Experimental design}

Twelve cassava genotypes ( six improved IITA genotypes: TMS 30001, TMS 91934, TMS 4(2) 1425, TMS 30572, TMS 50395, TMS 30555; four landraces [local genotypes] commonly grown in southwestern Nigeria: TME 1, TME 11, Isunikankiyan and Oko-Iyawo; and two landraces [local genotypes] adapted to mid-altitudes: Danduala and Danwaru). Cassava stem cuttings of $0.20 \mathrm{~m}$ length were collected from 12-monthold mother plants at the middle part of the stem and were immersed in 0.05 per cent of fungicidal benlate (a.i.=methyl 1-(butyl carbatomyl)-2benzimidazole carbamate) solution. The experiments were set up in each location in a completely randomized block design with three replications. Each plot had 6 rows, $10 \mathrm{~m}$ long, and spacing was $1 \mathrm{~m}$ between rows and $0.8 \mathrm{~m}$ within a row. Each plot contained 72 plants. Fields were kept free of weeds by regular hand-weeding.

\section{Data collection and analyses}

Harvesting was at 12 MAP. Cassava tuberous roots were brought to the laboratory immediately after the harvest. For each genotype, three healthy-looking tuberous roots were selected and treated as one sample. In genotypes with large tuberous roots ( $>5 \mathrm{~cm}$ in diameter), sampling was applied. Three discs were sampled per root, one each from each end (within $5 \mathrm{~cm}$ of the end), and the other from the middle of the root. The three root discs from each root were combined and treated as one sample. The samples were peeled and used to determine poundability. The samples were assigned labels and later put in cloth bags and cooked for $2 \mathrm{~h}$ at $100{ }^{\circ} \mathrm{C}$. The sample was 
pounded in crucible.

Poundability was determined using 1-3 scale, where $1=$ very poundable, $2=$ poundable, $3=$ not poundable. Statistical Analytical System (SAS, 1996) programme was used for data analyses. Analysis of Variance and Duncan's Multiple Range Test were used to evaluate significant differences in data collected.

\section{Results and discussion}

The results showed that there were no significant differences $(P<0.05)$ in tuberous root poundability between the two locations and years throughout the sampling periods (Fig. 1). No significant differences were observed in environmental effects, showing that cassava genotypes responded similarly to variation in environmental conditions concerning some biochemical changes like poundability. Similar results have been reported on cassava genotypes (Cock, 1985; Bueno, 1986; Akparobi et al., 2002) that

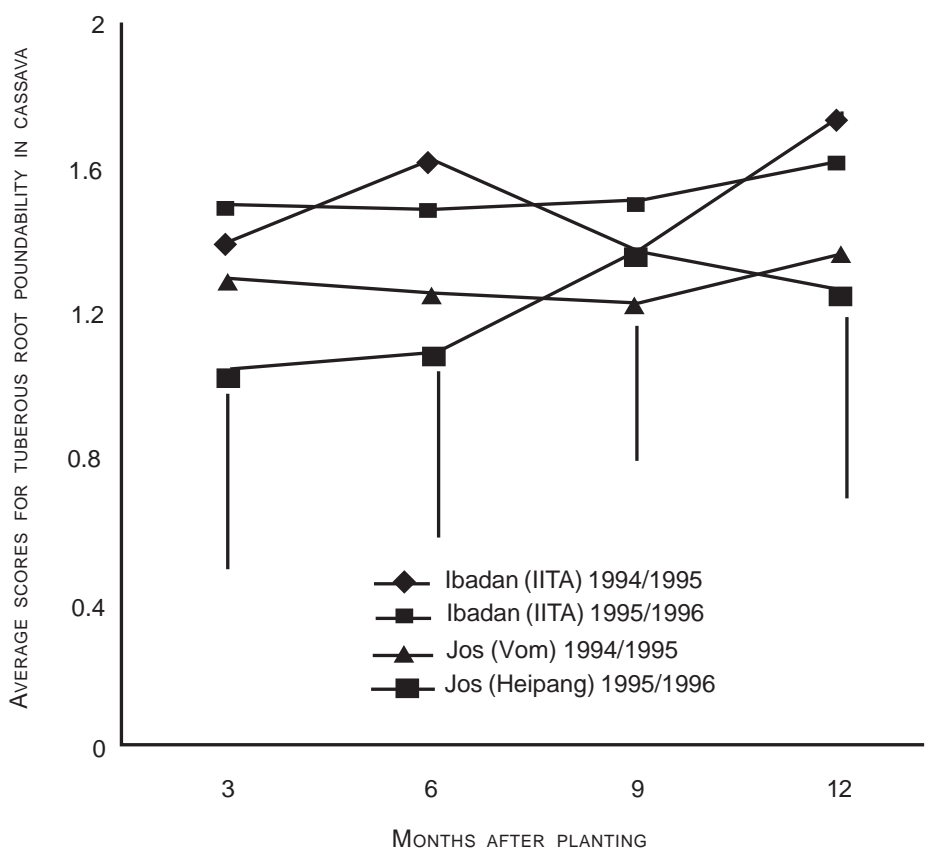

Fig. 1. Effect of two agroecological zones of Nigeria (Jos plateau and Ibadan) on tuberous root poundability of 12 cassava genotypes at 3, 6, 9 and 12 MAP. Bar represents LSD at $5 \%$ level of significance. environmental factors such as temperature, rainfall, solar radiation, and soil conditions sometimes have little influence on the biochemical and physiological processes of a cassava tuberous root. It seems there might be no need for testing at multiple locations over time for changes in biochemical parameters of cassava tuberous roots using poundability.

Genotypic differences $(P<0.05)$ were not observed among the cassava genotypes for tuberous root poundability either across locations (Table 1) or within locations (Table 2). Isunikankiyan, TME 1, TMS 50395, and TMS 30572 produced the lowest values for tuberous root poundability of 1.2, 1.3, 1.2 and 1.4 for 3, 6, 9 and 12 MAP, respectively (Table 1). This study implies that no significant differences exist among the genotypes, but some had lower values for poundability. These ones can be exploited by breeders by incorporating the traits for future breeding programmes, because many people prefer to buy poundable cassava (Hahn \& Keyser; 1985; Nweke, 1996). Similar results have been reported by Cock (1985), Ekanayake, Osiru \& Porto (1997), and Akparobi (2005) who observed varietal differences among cassava cultivars for biochemical parameters such as cyanide content and root taste.

Genotypic differences $(P<0.05)$ were observed among the tested genotypes for total dry tuberous root yield per hectare (Table 1). The highest tuberous root yields per hectare were produced by TMS 30572 , TMS 50395, TMS 91934, and TME 1 (Table 1).

The results of this study suggested that three genotypes, TME 1, TMS 50395 and TMS 30572, were found to be 
TABLE 1

Combined Analysis of 12 Cassava Genotypes as Affected by Tuberous Root Poundability and Total Dry Tuberous Root Yield in Two Agroecological Zones of Nigeria at 3, 6, 9 and 12 MAP from 1994 to 1996

\begin{tabular}{lccccc}
\hline & \multicolumn{5}{c}{ Tuberous root poundability } \\
Genotype & 3 MAP & 6 MAP & 9 MAP & 12 MAP & $\begin{array}{c}\text { Tuberous root } \\
\text { dry weight }\left(t \text { h }^{-1}\right)\end{array}$ \\
\cline { 2 - 5 } Isunikankiyan & $1.1 \mathrm{a}$ & $1.4 \mathrm{a}$ & $1.3 \mathrm{a}$ & $1.5 \mathrm{a}$ & $1.8 \mathrm{c}$ \\
TMS 30001 & $1.1 \mathrm{a}$ & $1.5 \mathrm{a}$ & $1.5 \mathrm{a}$ & $1.6 \mathrm{a}$ & $4.5 \mathrm{~b}$ \\
TME 2 & $1.5 \mathrm{a}$ & $1.4 \mathrm{a}$ & $1.4 \mathrm{a}$ & $1.7 \mathrm{a}$ & $4.4 \mathrm{~b}$ \\
TMS 30572 & $1.0 \mathrm{a}$ & $1.5 \mathrm{a}$ & $1.4 \mathrm{a}$ & $1.4 \mathrm{a}$ & $7.1 \mathrm{a}$ \\
TMS 4(2) 1425 & $1.4 \mathrm{a}$ & $1.4 \mathrm{a}$ & $1.3 \mathrm{a}$ & $1.5 \mathrm{a}$ & $5.2 \mathrm{ab}$ \\
Danwaru & $1.4 \mathrm{a}$ & $1.4 \mathrm{a}$ & $1.4 \mathrm{a}$ & $1.6 \mathrm{a}$ & $2.1 \mathrm{c}$ \\
TMS 50395 & $1.2 \mathrm{a}$ & $1.3 \mathrm{a}$ & $1.2 \mathrm{a}$ & $1.5 \mathrm{a}$ & $5.4 \mathrm{ab}$ \\
TMS 91934 & $1.4 \mathrm{a}$ & $1.4 \mathrm{a}$ & $1.4 \mathrm{a}$ & $1.7 \mathrm{a}$ & $6.2 \mathrm{a}$ \\
Danduala & $1.5 \mathrm{a}$ & $1.6 \mathrm{a}$ & $1.3 \mathrm{a}$ & $1.6 \mathrm{a}$ & $1.6 \mathrm{c}$ \\
Oko-Iyawo & $1.6 \mathrm{a}$ & $1.5 \mathrm{a}$ & $1.4 \mathrm{a}$ & $1.5 \mathrm{a}$ & $4.8 \mathrm{~b}$ \\
TME 1 & $1.2 \mathrm{a}$ & $1.3 \mathrm{a}$ & $1.3 \mathrm{a}$ & $1.5 \mathrm{a}$ & $6.1 \mathrm{a}$ \\
TMS 30555 & $1.4 \mathrm{a}$ & $1.5 \mathrm{a}$ & $1.4 \mathrm{a}$ & $1.5 \mathrm{a}$ & $4.4 \mathrm{~b}$ \\
\hline
\end{tabular}

Means in the same column with the same letter (s) and within the same MAP are not significantly different $(P<0.05)$, using DMRT. MAP = months after planting.

TABLE 2

Effect of Tuberous Root Poundability on 12 Cassava Genotypes in Two Agroecological Zones at 3, 6, 9 and 12 MAP from 1994 to 1996

\begin{tabular}{lcccccccc}
\hline & \multicolumn{3}{c}{ Tuberous root poundability } & \multicolumn{5}{c}{ Tuberous root poundability } \\
& \multicolumn{4}{c}{ Ibadan } & & \multicolumn{3}{c}{ Jos Plateau } \\
\cline { 2 - 8 } Genotype & 3 MAP & 6 MAP & 9 MAP & 12 MAP & 3 MAP & 6 MAP & 9 MAP & 12 MAP \\
\hline Isunikankiyan & $1.2 \mathrm{a}$ & $1.3 \mathrm{a}$ & $1.4 \mathrm{a}$ & $1.5 \mathrm{a}$ & $1.3 \mathrm{a}$ & $1.4 \mathrm{a}$ & $1.5 \mathrm{a}$ & $1.4 \mathrm{a}$ \\
TMS 30001 & $1.3 \mathrm{a}$ & $1.5 \mathrm{a}$ & $1.5 \mathrm{a}$ & $1.6 \mathrm{a}$ & $1.4 \mathrm{a}$ & $1.5 \mathrm{a}$ & $1.6 \mathrm{a}$ & $1.7 \mathrm{a}$ \\
TME 2 & $1.5 \mathrm{a}$ & $1.4 \mathrm{a}$ & $1.5 \mathrm{a}$ & $1.5 \mathrm{a}$ & $1.5 \mathrm{a}$ & $1.5 \mathrm{a}$ & $1.7 \mathrm{a}$ & $1.6 \mathrm{a}$ \\
TMS 30572 & $1.3 \mathrm{a}$ & $1.4 \mathrm{a}$ & $1.4 \mathrm{a}$ & $1.4 \mathrm{a}$ & $1.4 \mathrm{a}$ & $1.6 \mathrm{a}$ & $1.4 \mathrm{a}$ & $1.3 \mathrm{a}$ \\
TMS 4(2) 1425 & $1.4 \mathrm{a}$ & $1.6 \mathrm{a}$ & $1.4 \mathrm{a}$ & $1.6 \mathrm{a}$ & $1.7 \mathrm{a}$ & $1.5 \mathrm{a}$ & $1.9 \mathrm{a}$ & $1.8 \mathrm{a}$ \\
Danwaru & $1.5 \mathrm{a}$ & $1.5 \mathrm{a}$ & $1.5 \mathrm{a}$ & $1.6 \mathrm{a}$ & $1.6 \mathrm{a}$ & $1.6 \mathrm{a}$ & $1.6 \mathrm{a}$ & $1.7 \mathrm{a}$ \\
TMS 50395 & $1.3 \mathrm{a}$ & $1.4 \mathrm{a}$ & $1.2 \mathrm{a}$ & $1.5 \mathrm{a}$ & $1.4 \mathrm{a}$ & $1.5 \mathrm{a}$ & $1.5 \mathrm{a}$ & $1.4 \mathrm{a}$ \\
TMS 91934 & $1.5 \mathrm{a}$ & $1.4 \mathrm{a}$ & $1.4 \mathrm{a}$ & $1.7 \mathrm{a}$ & $1.6 \mathrm{a}$ & $1.4 \mathrm{a}$ & $1.4 \mathrm{a}$ & $1.6 \mathrm{a}$ \\
Danduala & $1.5 \mathrm{a}$ & $15 \mathrm{a}$ & $1.5 \mathrm{a}$ & $1.8 \mathrm{a}$ & $1.9 \mathrm{a}$ & $1.5 \mathrm{a}$ & $1.9 \mathrm{a}$ & $1.9 \mathrm{a}$ \\
Oko-Iyawo & $1.5 \mathrm{a}$ & $1.4 \mathrm{a}$ & $1.3 \mathrm{a}$ & $1.7 \mathrm{a}$ & $1.5 \mathrm{a}$ & $1.4 \mathrm{a}$ & $1.9 \mathrm{a}$ & $1.8 \mathrm{a}$ \\
TME 1 & $1.3 \mathrm{a}$ & $1.3 \mathrm{a}$ & $1.3 \mathrm{a}$ & $1.4 \mathrm{a}$ & $1.5 \mathrm{a}$ & $1.3 \mathrm{a}$ & $1.5 \mathrm{a}$ & $1.4 \mathrm{a}$ \\
TMS 30555 & $1.4 \mathrm{a}$ & $1.5 \mathrm{a}$ & $1.4 \mathrm{a}$ & $1.7 \mathrm{a}$ & $1.6 \mathrm{a}$ & $1.7 \mathrm{a}$ & $1.8 \mathrm{a}$ & $1.5 \mathrm{a}$ \\
\hline
\end{tabular}

Means in the same column with the same letter (s) and within the same MAP are not significantly different $(P<0.05)$, using DMRT. MAP = months after planting. 
poundable and also had high tuberous root dry weight, and should be made available to farmers for 'on-farm testing'. These identified genotypes should be used for further breeding programmes, so that the trait would be incorporated.

\section{Acknowledgement}

This study was funded by the core budget of the International Institute of Tropical Agriculture (IITA). The author acknowledges the assistance of Dr I. J. Ekanayake and Dr A. G. O. Dixon in the work.

\section{REFERENCES}

Akparobi, S. O., Ekanayake, I. J. \& Togun, A. O. (2002) Genotypic variability for cassava tuberous root development in two low altitude and mid altitude savanna sites of Nigeria. African Journal of Root and Tuber Crops 5(1), 24-28.

Akparobi, S. O. (2005) Screening cassava genotypes using tuberous root taste. UNISWA Journal Agriculture 13, 96-101.

Bueno, A. (1986) Adequate number of environments to evaluate cassava cultivars. Rev. Bras. Mandioca 5, 83-93.

CIAT (1993) Cassava: The latest facts about an ancient crop. Centro internacional de agricultural tropical (CIAT), Cali, Colombia. Apartado Aereo 713. 10 pp.

Carter, S. E., Fresco, L. O., Jones, P. G. \& Fairbairn, J. N. (1992) An atlas of cassava in Africa: Historical, agroecological and demographical aspects of distribution. CIAT, Cali, Colombia. 86 pp.

Cock, J. H. (1985) Cassava: New potential for a neglected crop. Westview Press, Boulder, Colorado. $79 \mathrm{pp}$.

Dixon, A. G. O., Asiedu, R. \& Hahn, S. K. (1994)
Genetic stability and adaptability: Analytical methods and implications for cassava breeding for low input agriculture. In Proceedings of the Ninth Symposium of the International Society for Tropical Root and Crops, Accra, Ghana, 20-26, October 1991. pp. 130-137.

Ekanayake, I. J., Osiru, D. S. O. \& Porto, M. C. M. (1997) Physiology of cassava. IITA Research Guide 60. Training Program, IITA, Ibadan, Nigeria, 22 pp.

FAO (1996) FAO Food Outlook. March-April, 1996. pp. 19-22.

Greenland, D. J. (1981) Characteristics of soils in relation to their classification and management for crop production from areas of humid tropics. Oxford University Press, New York, USA. 466 pp.

Hahn, S. K. \& Keyser, J. (1985) Cassava: A basic food of Africa. Outlook on Agriculture 14(2), 96100.

Kowal, T. M. \& Knabe, D. T. (1972) An agroclimatological atlas of the Northern States of Nigeria with explanatory notes. Ahmadu Bello University Press, Zaria, Nigeria. 211 pp.

Nweke, F. I. (1996) Cassava processing in sub-Saharan Africa: Implications for expanding cassava production. IITA Research No. 12, pp. 7-14.

Odogola, W. R. (1994) A comparative study of solar and open sundrying of cassava chips in Uganda. In Proceedings of the Ninth Symposium of the International Society for Tropical Root and Crops, Accra, Ghana, 20-26 October 1991. pp. 274-282.

Sanni, M. O. (1994) Gari processing in Ibadan metropolis: Factors controlling quality at the smallscale level. In Proceedings of the Ninth Symposium of the International Society for Tropical Root and Crops, Accra, Ghana, 20-26 October 1991. pp. 256260.

SAS (1996) SAS user's guide. Statistics Version 6, SAS Institute Inc., Raleigh, NC USA. 956 pp. 